\title{
EFFECT OF VETIVER ROOTS ON SOIL RESISTANCE TO PENETRATION IN A TYPIC FLUVIC NEOSSOL IN THE SÃO FRANCISCO RIVERBANK ${ }^{1}$
}

\author{
LORENA MACHADO ${ }^{2 *}$, FRANCISCO SANDRO RODRIGUES HOLANDA ${ }^{2}$, ALCEU PEDROTTI $^{2}$, OLAVO JOSÉ \\ MARQUES FERREIRA ${ }^{2}$, RENISSON NEPONUCENO DE ARAÚJO FILHO ${ }^{3}$, MARKS MELO MOURA $^{2}$
}

\begin{abstract}
The aim of this study was to evaluate the effect of the root of vetiver grass (Chrysopogon zizanioides (L.) Robert) on the soil Resistance to penetration (RP) in the margins of the lower São Francisco River. Vetiver grass seedlings were planted on the riverbank margins in order to increase soil resistance to erosion processes, and RP assessments were made at soil depths of 0-0.20, 0.20-0.40, and 0.40-0.60 $\mathrm{m}$ in different situations (near the plants and within rows). RP data was obtained using an automated penetrometer. Gravimetric moisture data was also collected, as well as particle size data by densimetry, and root density data by the monolith method. The results of the RP, moisture, and root density studies were subjected to analysis of variance $(p<0.05)$ and then the averages were compared by the Tukey test using SISVAR software. The samples next to the vetiver grass showed an average RP of $1793.94 \mathrm{kPa}$ and an average moisture content of $11.78 \%$, statistically differing from that of the sampled points within rows. RP and soil moisture did not differ statistically at the depth assessed. The vetiver grass produced an adequate ground cover, leading to higher water retention and hence a reduced resistance to penetration.
\end{abstract}

Keywords: Chrysopogon zizanioides. Erosion. Soil bioengineering.

\section{EFEITO DE RAÍZES DE VETIVER SOBRE A RESISTÊNCIA À PENETRAÇÃO DE UM NEOSSOLO FLÚVICO NAS MARGENS DO RIO SÃO FRANCISCO}

RESUMO - O objetivo deste estudo foi avaliar o efeito da raiz de capim vetiver (Chrysopogon zizanioides (L.) Robert) sobre a resistência à penetração (RP) das margens do Baixo São Francisco. Mudas de vetiver foram plantadas no talude do rio, a fim de aumentar a resistência do solo aos processos erosivos, com avaliações de Resistência à Penetração (RP) realizadas em profundidades de 0 a $0,20,0,20$ a 0,40 , e $0,40-0,60 \mathrm{~m}$ em diferentes situações (próximo à planta e, nas entre linhas). Dados de RP foram obtidos utilizando um penetrômetro automatizado. Amostras de solo foram coletadas para a determinação da umidade assim como da textura do solo, que foi determinada por densimetria, a densidade das raízes pelo método monólito. Os resultados do RP, umidade, e estudos de densidade de raiz foram submetidos a análise de variância $(p<0,05)$ e, em seguida, as médias foram comparadas pelo teste de Tukey utilizando o software SISVAR. As amostras próximas ao vetiver apresentaram uma RP média de 1793,94 $\mathrm{kPa}$ e umidade média de 11,78\%, diferindo estatisticamente dos pontos amostrados nas entrelinhas. RP e umidade do solo não diferiram estatisticamente com a profundidade do solo. O capim vetiver produziu uma cobertura do solo adequada, levando a uma maior retenção de água e, consequentemente, uma redução da resistência à penetração.

Palavras-chave: Chrysopogon zizanioides. Erosão. Bioengenharia de solos.

\footnotetext{
${ }^{*}$ Corresponding author

${ }^{1}$ Received for publication in 10/07/2016; accepted in 02/08/2018.

Paper extracted from the master thesis of the first author.

${ }^{2}$ Department of Agronomic Engineering, Universidade Federal de Sergipe, SE, Brazil; loremachado@globo.com - ORCID: 0000-00020149-2129, fholanda@infonet.com.br - ORCID: 0000-0001-6812-6679, alceupedrotti@gmail.com - ORCID: 0000-0003-3086-8399, olavojose@hotmail.com - ORCID: 0000-0003-1105-0233, marksmoura@yahoo.com.br - ORCID: 0000-0002-2964-8527.

${ }^{3}$ Department of Forest Engineering, Universidade Federal do Tocantins, TO, Brazil; renisson@uft.edu.br - ORCID: 0000-0002-9747-1276.
} 


\section{INTRODUCTION}

Due to the deployment of hydroelectric power plants, the São Francisco River has experienced an alteration of its hydrological regime. A gradual erosion of its banks has been occurring in its lower course, located between the states of Sergipe and Alagoas in northeast Brazil, through the undercutting of the river bank base associated with the deforestation of the riparian vegetation (ROCHA et al., 2013).

Soil bioengineering and natural engineering techniques are being tested in the Lower São Francisco basin as low cost alternatives to stabilize the riverbanks (HOLANDA et al., 2009). According to Stokes et al. (2014), soil bioengineering is defined as a technology that uses components of engineering in combination with integrated ecological principles in order to assemble and maintain living vegetation and quickly repair damage caused by erosion. Vegetation can contribute to the processes mentioned above in a number of ways, such as in the mechanical reinforcement of the soil by roots, which prevents mass movements and contributes to the stabilization of ravines and embankments (DE BAETS et al., 2008; OUYANG et al., 2010).

As a structural component of soil bioengineering techniques, vetiver grass (Chrysopogon zizanioides (L.) Robert) has been used on the right bank of the São Francisco River to mechanically reinforce and stabilize the bank (HOLANDA et al., 2012). According to Chong and Chu (2007) and Mickovski and Van Beek (2009), the use of vetiver grass is recommended for the control of riverbank erosion due to the following reasons: it forms a living and dense plant barrier that retains sediment and reduces the potential energy of surface runoff; it is highly adaptable to different soil and weather conditions; and it has a penetrating root system able to withstand fissures in soil structures.

Among the physical qualities of soil, soil resistance to penetration (RP) is the one that roots actually encounter, and it is therefore considered the more suitable property to measure when assessing soil compaction (IORI et al., 2012). Soil RP is directly correlated with soil texture, density, organic matter, and especially, moisture at the time of measurement (PEDROTTI et al., 2001). In general, compacted soils have low infiltration capacity, which causes a greater runoff, and consequently greater erosion. According to Souza and Alves (2003), the degree of compaction and the discontinuity of pores are responsible for the reduction in the permeability of soil to water, and different forms of soil use and management promote changes in water movement in the soil and in RP. Areas with appropriate management practices have lower soil RP and higher infiltration capacity and hydraulic conductivity (OLIVEIRA; SOUZA, 2013).

The measurement of soil RP evaluates the degree of impediment to root growth, and from it may be extrapolated the potential for water infiltration into the soil. According to the USDA (1993), soil RP can be classified into three classes according to the restriction of root growth: small (less than $100 \mathrm{kPa}$ ), intermediate (between 100 and $2000 \mathrm{kPa}$ ), and large (greater than $2000 \mathrm{kPa}$ ).

The aim of this study was to evaluate the effect of the root of vetiver grass (Chrysopogon zizanioides (L.) Robert) on the soil RP in the margins of the lower São Francisco River.

\section{MATERIAL AND METHODS}

\section{Description of the experimental area}

The study was carried out on the right bank of the São Francisco River, in the municipality of Amparo do São Francisco, Sergipe, Brazil, with $\mathrm{W} 36^{\circ} 50^{\prime} 25.335^{\prime \prime}$ and $\mathrm{S} 10^{\circ} 13^{\prime} 34.081 "$ (Figure 1). The climate of the site, according to the Köppen (1948) classification, is type Am (tropical monsoon), with rainfall and mean annual temperature of $744 \mathrm{~mm} \mathrm{y}^{-1}$ and $25^{\circ} \mathrm{C}$, respectively (CODEVASF, 2003), and the soil is classified as Typic Fluvic Neossol according to Santos et al. (2013).

Soil bioengineering techniques were implemented in July 2011 to control the erosion process of the riverbank at the experimental site. The river bank of the studied area has a sharp retreat of the bank line, granulometric composition with predominance of medium and fine sand fractions, high friability, and proximity to the thalweg of the river.

Seedlings of vetiver grass were planted in order to increase the resistance and cohesion of the soil, reduce surface erosion, and consequently, provide greater slope stability. The planting of the grass was carried out in pits fertilized with $8 \mathrm{~g}$ of simple superphosphate per plant using the system of beads in contours perpendicular to the slope of the riverbank and with $0.9 \mathrm{~m}$ spacing between rows and $0.3 \mathrm{~m}$ between plants in a row.

The sampling of soil and roots was carried out during the dry season in 2013 to assess the effect of this grass on soil RP, humidity retention, and production of roots. It was considered important to test adult plants in order to assess the influence of the establishment of the grass on the physical characteristics of the soil slope.

The experimental design was a complete randomized block design, performing eight blocks with $16 \mathrm{~m}^{2}$ each. They were arranged in a $2 \times 3$ factorial design with four replications corresponding to two points of soil sampling (next to the vetiver grass and within rows, in the gaps between plants) and three different sampling depths (0-0.20, $0.20-0.40$, and $0.40-0.60 \mathrm{~m})$. 


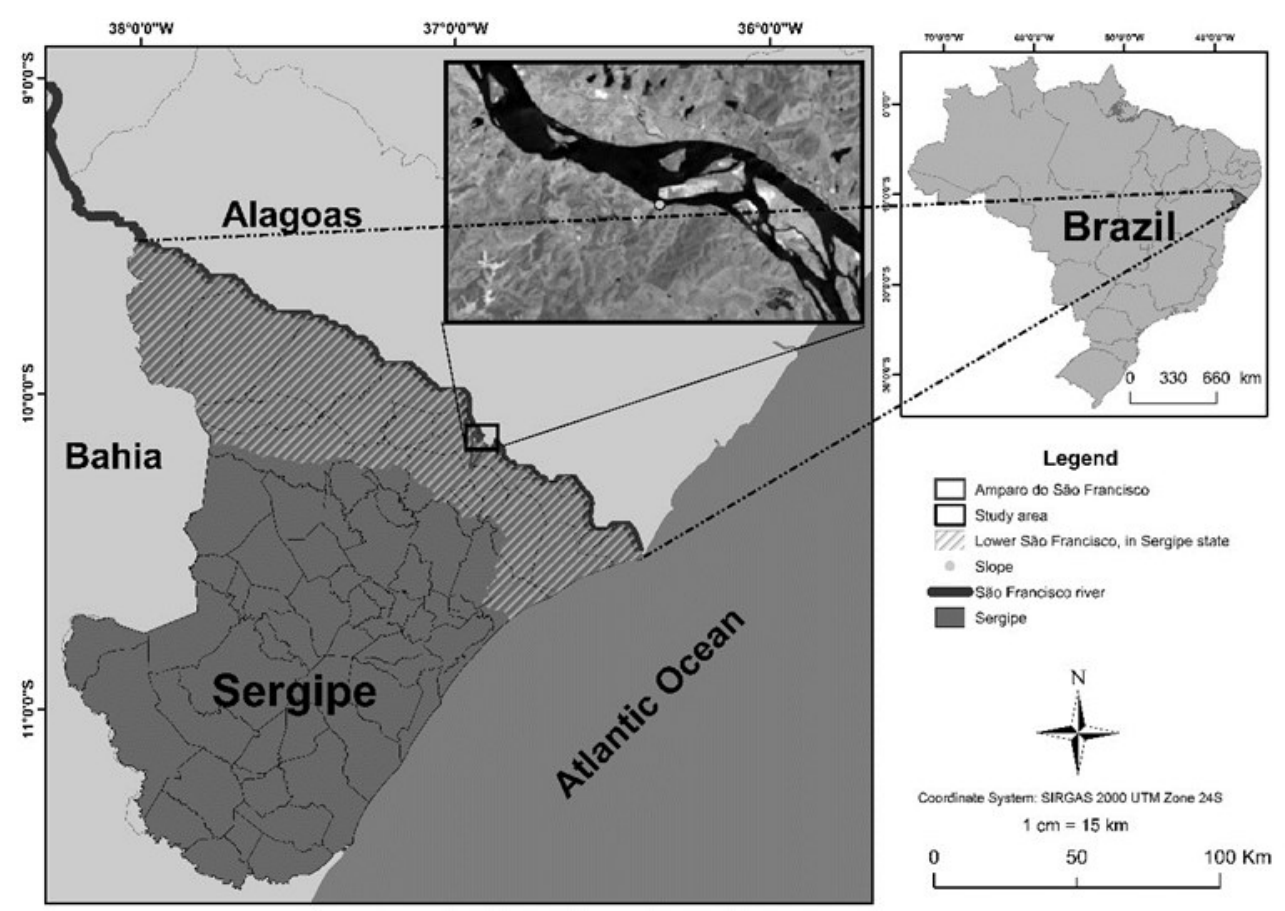

Figure 1. Location of the study area, municipality of Amparo de São Francisco - SE.

\section{Soil resistance to penetration}

Soil mechanical RP was assessed along the soil profile to a depth of $0.60 \mathrm{~m}$, using an automated Solo Track PLG5300 soil compaction meter. The automated penetrometer was configured to record data on resistance at each centimeter of depth.

Two samples were taken for each block to evaluate the dynamics of RP in the presence of grass. One was taken next to the vetiver grass and another within rows in the gaps between the grass plantings,

The RP data obtained was grouped and analyzed for each sampling point at three depths: $0-0.20,0.20-0.40$, and $0.40-0.60 \mathrm{~m}$.

\section{Soil moisture and texture}

Samples were also collected to determine soil moisture content and texture at the same sampling points and depths where RP was measured. Three samples per treatment were collected for each depth, totaling 144 samples. According to the obtained soil texture for the three analyzed depths, the textural classification of the soil was sandy loam $(65.71 \%$ sand, $18.19 \%$ silt, and $16.10 \%$ clay).

The moisture content was determined by the gravimetric method (DONAGEMA et al., 2011), and the samples were properly kept in order to measure the weight of the wet soil and then dried in an oven at $105^{\circ} \mathrm{C}$ until they reached a constant weight.

Using a symmetrical bulb hydrometer (Bouyoucos hydrometer) graduated from 0.995 to 1.050 , the particle size analysis was performed by densimetry according Bouyoucos (1962).

\section{Root density}

The methodology used for the collection of roots was the monolith method described by Böhm (2012). The dimensions of each monolith were $0.50 \mathrm{~m}$ wide, $0.50 \mathrm{~m}$ long, and $0.10 \mathrm{~m}$ high. The sampling was carried out in layers at depths of $0-0.10, \quad 0.10-0.20, \quad 0.20-0.30, \quad 0.30-0.40$, and $0.40-0.50 \mathrm{~m}$, with five individuals of vetiver grass randomly chosen in the experimental area. The roots were washed with a water jet, placed in paper bags, and dried in an oven with forced air circulation at $65{ }^{\circ} \mathrm{C}$ for $72 \mathrm{~h}$.

Thereafter the weight of the roots was determined using an analytical balance to calculate dry root matter (DRM), which enabled the calculation of Root Density $(R D)$ by means of Eq. (1), where $M_{D}$ is the mass of the roots by depth class $(\mathrm{kg})$, and $V$ is volume of soil for each class $\left(\mathrm{m}^{3}\right)$.

$$
D R=\frac{M_{D}}{V}
$$

\section{Statistical Analysis}

The data on soil RP and soil moisture was processed and submitted to analysis of variance, comparing the sampling points and the depth of collection. The root density data obtained for the different classes of soil depth was also submitted to analysis of variance to determine the significance at $5 \%$ (F-Test). For comparison of the averages, the Tukey test was applied using SISVAR software (FERREIRA, 2011). 


\section{RESULTS AND DISCUSSION}

The soil RP and humidity were significantly different $(\mathrm{p}<0.01)$ at the different sampling points (Table 1). The analysis of variance applied to RP and soil moisture measurements did not show significant interaction by the F-Test between the sampling points and the soil depth, but also did not differ significantly in the sampled depths.

Table 1. RP and soil moisture near the vetiver grass and within rows.

\begin{tabular}{lll}
\hline & $\mathrm{RP}(\mathrm{kPa})$ & Soil Moisture (\%) \\
\hline Near vetiver grass & $1793.94 \mathrm{~b} *$ & $11.78 \mathrm{a}$ \\
Within rows & $2152.25 \mathrm{a}$ & $7.78 \mathrm{~b}$ \\
\hline
\end{tabular}

*Means followed by the same letter do not differ by the Tukey test at $1 \%$ probability.

Higher values of RP were found in samples collected within rows in the gaps between the plantings, displaying an average of $2152.25 \mathrm{kPa}$ $(\mathrm{p}<0.01)$ (Table 1). The presence of grass contributed to the reduction of RP due to greater aggregation of soil through their roots. Vegetation cover with grass promotes a greater recovery rate from soil aggregation, especially in degraded soils (SUZUKI et al., 2007; OLA et al., 2015; STUMPF et al., 2016) and root mass had a positive relationship with soil strength (GOULD et al., 2016).

According to Table 1, the higher average of moisture content, $11.78 \%(\mathrm{p}<0.01)$, was recorded at sampling points near to the vetiver grass plants. Although the depth levels did not influence the water content in the soil, it can be observed from Figure 2 that at all the studied depths $(0-0.20,0.20-0.40$, and $0.40-0.60 \mathrm{~m})$, the average moisture was higher in sampling points near the grass than within rows $(p<0.01)$. This can be explained by the higher water retention next to the vetiver grass plants due to soil cover, in addition to an increased infiltration rate provided by the presence of the grass roots. According to Holanda et al. (2010), the elements of this biotechnique decrease the solar exposure of the soil, allowing longer maintenance of higher humidity. Also, Jotisankasa and Mairaing (2014) report that the root-reinforced soil is expected to be of higher strength as well as higher permeability, which would help to reduce runoff by providing more infiltration, thus improving the soil and water conservation.

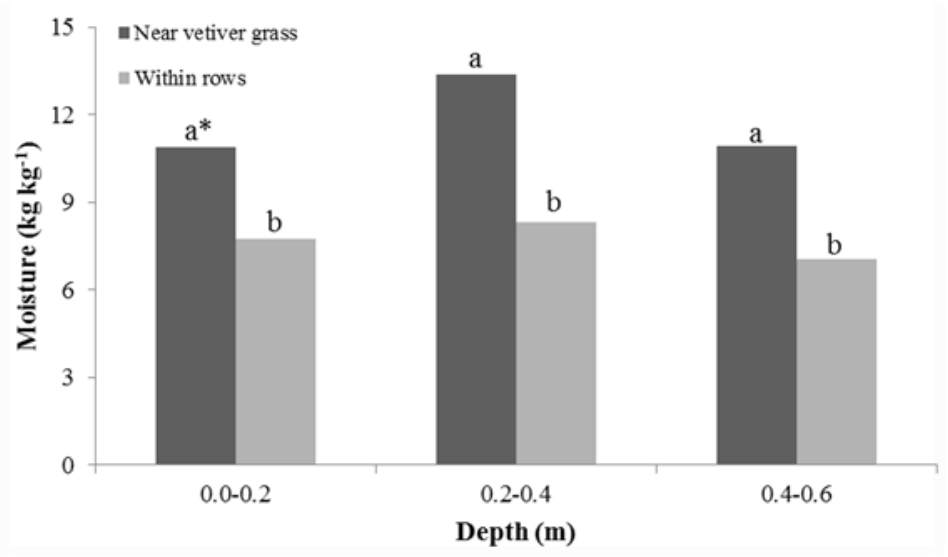

Figure 2. Soil moisture for the Neossolo Flúvico of the riverbank of the Lower São Francisco River at different depths, measured near the plants and within rows. *Means followed by the same letter do not differ by the Tukey test at $1 \%$ probability.

Similar results were discussed by Lanzanova et al. (2010), who observed higher water content in the management system of native pastures due to the dense and permanent soil cover provided by grass, which functioned as an obstacle to atmospheric evaporative processes in periods of water stress.
They observed less moisture within rows with lower soil coverage owing to possible sealing of the surface, which made it difficult for water to infiltrate the soil.

There was no difference in textural classification both between the analyzed points and 
between the depths; the texture does not give enough explanation on the differences at different points. As expected regarding Fluvic Neossols, there is high vertical spatial variability in the soil particles (Figure 3 ), even though in the studied area its texture classification did not change whatsoever. According to Rosolem et al. (1999), the less clay in the soil, the lower the resistance to penetration at the same level of global density.

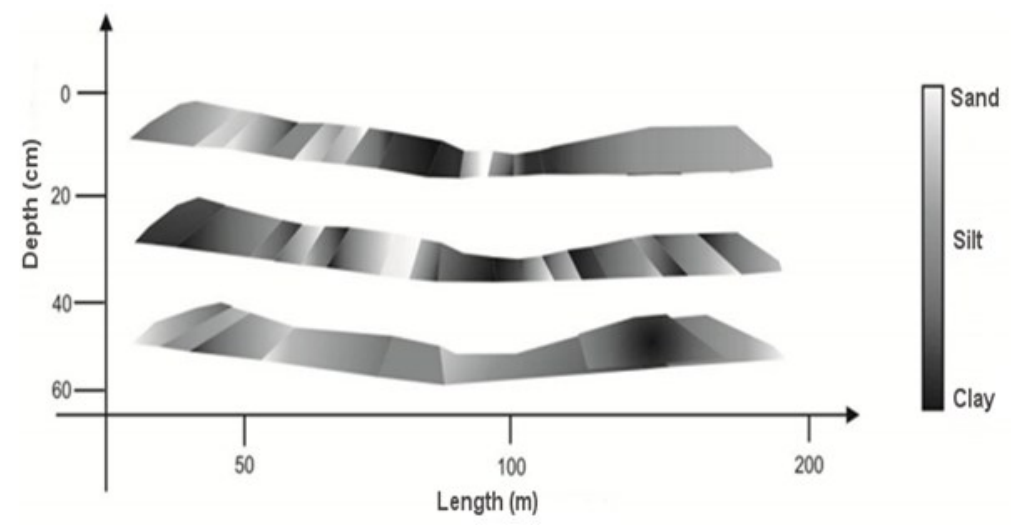

Figure 3. Schematic representation of texture in the experimental area at three depths $(0-20,20-40$ and $40-60 \mathrm{~cm})$ of the Fluvic Neossol.

Figure 4 shows that the values of RP in the $0-0.20 \mathrm{~m}$ layer vary from 653.12 to $2189.88 \mathrm{kPa}$ for the samples taken next to vetiver grass, and 1175.20 to $2.632 \mathrm{kPa}$ for the samples taken within rows.

At a depth of $0-20 \mathrm{~m}$, the average moisture and the average RP in points located near the plants were of $10.90 \%$ and $1768.96 \mathrm{kPa}$, respectively, different than the average found within rows, $7.76 \%$ and $2261.16 \mathrm{kPa}$ (Figure 4). The reduction in the water content in samples within rows is in agreement with the increase of RP at those points. In agreement with the presented data, Silveira et al. (2010) found a high negative correlation between RP and soil moisture at an orange orchard (Citrus limonia Osbeck) intercropped with jack beans (Canavalia ensiformis L.). Vaz et al. (2011) applied a correction of soil penetration, varying the water content of the soil (functioning properly in four oxisols) with well-known texture and uniform soil structure, which is very different from the spatial variability of these parameters in Fluvial Neosols. The relationship of $\mathrm{RP}$ and humidity in the area at an experimental depth of $0-0.20 \mathrm{~m}$ is similar to that obtained by Campos and Alves (2006). They assessed a degraded area in the process of natural regeneration and a recovery area with Pinus and found average values of RP of 1953.3 and $2656.6 \mathrm{kPa}$ and moisture values of 12.4 and $11.5 \%$, respectively, in sandy clay loam soil. Regardless of soil humidity, Celik et al. (2010) found similar values to RP also in growing grass species. On the other hand, Lanzanova et al. (2010) working with soil of the same sandy loam texture in areas of native grass and soil without coverage, found an RP of approximately $660 \mathrm{kPa}$ for soil without coverage and $800 \mathrm{kPa}$ for a system with native grass at a depth of $0-0.20 \mathrm{~m}$.

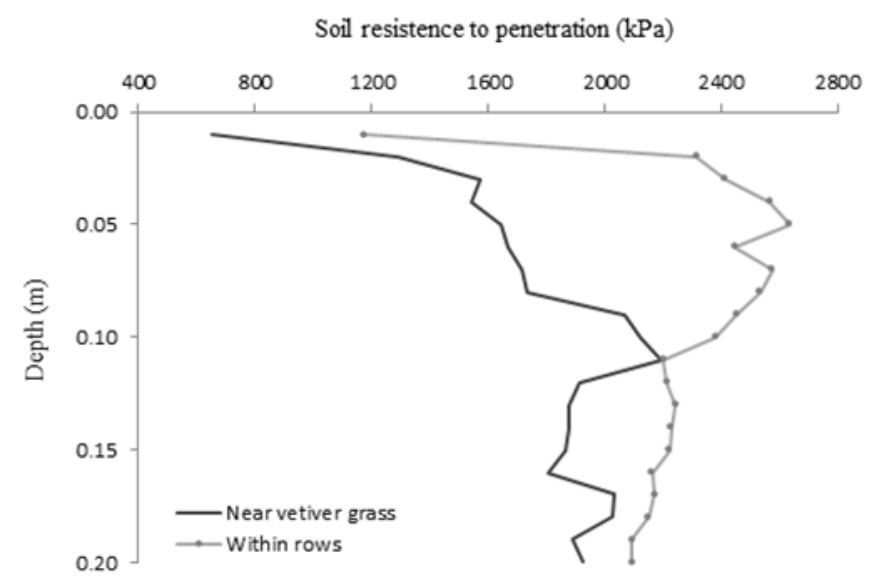

Figure 4. Mechanical resistance of the Neossolo Flúvico to penetration (RP) at 0-0.20 m depth, at points close to vetiver grass plants and within rows. 
It is important to note that in the first ten centimeters of the topsoil, a greater range of RP values between the studied points was found and this may be explained by the greater root density (RD) at this depth near the plant (Figure 5). Cobra et al. (2012) state that the greater the age of the vetiver grass in a revegetated bank, the greater the root density and, consequently, the lower the RP.

This high concentration of roots at a depth of $0-0.10 \mathrm{~m}$ provides higher soil aggregation, increased water infiltration and, consequently, less erosion. The increase in water infiltration in the soil from the presence of grasses is possibly related to the increase in organic matter on the soil surface, which is able to reduce runoff and erosion. Podwojewski et al. (2011) state that in the long term, vegetation influences the fluxes of water and sediments by increasing the soil aggregate stability and cohesion and by improving water infiltration avoiding soil erosion.

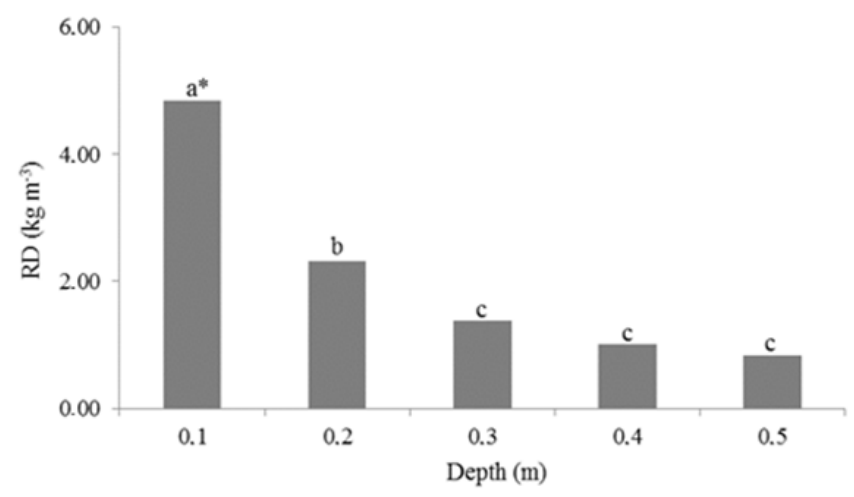

Figure 5. Root density (RD) of vetiver grass in the experimental area at different soil depths. *Means followed by the same letter do not differ by the Tukey test at $1 \%$ probability.

At a depth of $0.20-0.40 \mathrm{~m}$ (Figure 6), the RP measurements were higher within rows $(2139.92 \mathrm{kPa})$ than at points next to the vetiver grass $(1896.51 \mathrm{kPa})$. This behavior in the study area, as well as at $0-0.20 \mathrm{~m}$, is explained by the lack of plant coverage and lower root density within rows and the higher water content in the soil near the plants, resulting in $13.4 \%$ versus $8.32 \%$ of water content, respectively. Zhao et al. (2017) indicate that greater root development may create more large pores and increase porosities and macro-porosities as well as giving differences in improved aggregate microstructure by vegetation restoration, which could be due to the increase in the root system. When studying soil grown with Brachiaria brizantha, Magalhães et al. (2009) observed an average RP value of approximately $2485 \mathrm{kPa}$ at a depth of $0.20-0.40 \mathrm{~m}$.

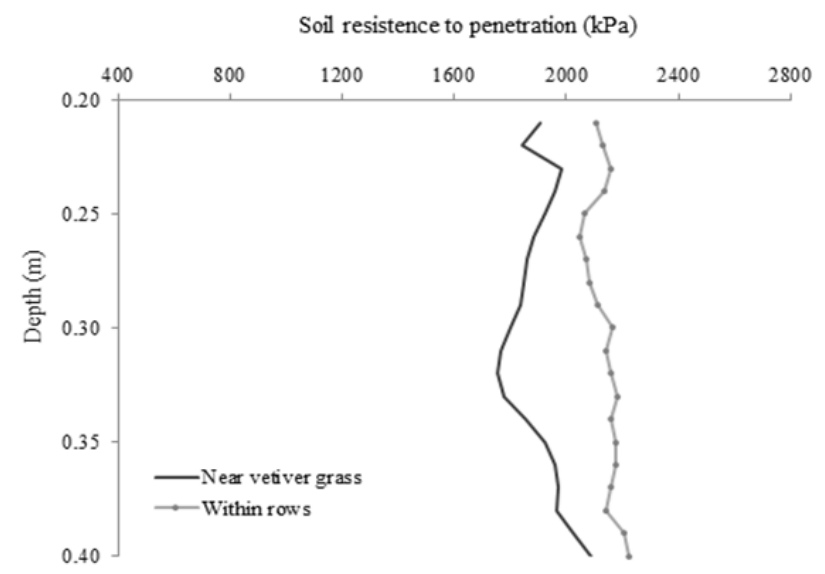

Figure 6. Mechanical resistance of the Neossolo Flúvico to penetration at a depth of $0.20-0.40 \mathrm{~m}$, at points near to vetiver grass plant and at points within rows.

The lowest levels of water identified in this study justify the higher RP observed in the experimental area, explained by the decrease of root density mostly located between rows.

Figure 7 details the behavior of RP in the 0.40 $-0.60 \mathrm{~m}$ profile. For each centimeter analyzed, the
RP near the vetiver grass was lower than the RP within rows. The RP in the vicinity of the plants ranged from 1529.62 to $1841.37 \mathrm{kPa}$ with an average value of $1716.35 \mathrm{kPa}$, while the minimum and maximum values found within rows were, 1764.25 
and $2233.62 \mathrm{kPa}$ respectively, with an average value of $2055.96 \mathrm{kPa}$.

The behavior of RP between the sampling points is inversely proportional to the water content in the soil. The points near the vetiver grass had a moisture content of $10.92 \%$, while the average moisture within rows was $7.06 \%$. Cobra et al. (2012) studied 17-month old vetiver grass and observed an $\mathrm{RP}$ of $552.5 \mathrm{kPa}$ at a depth of $0.40-0.60 \mathrm{~m}$, but found no correlation with moisture and soil texture.

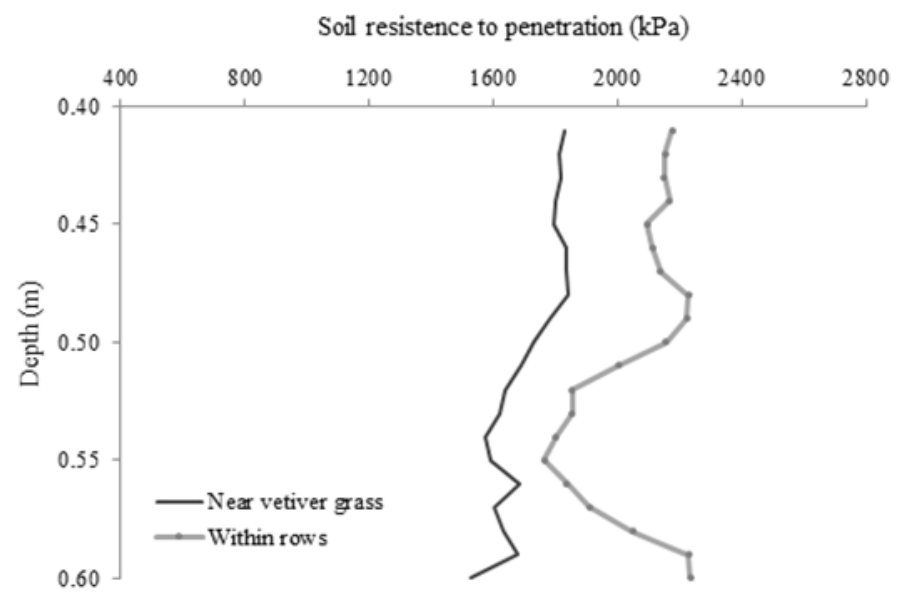

Figure 7. Mechanical resistance of the Neossolo Flúvico to penetration at $0.40-0.60 \mathrm{~m}$ depth, at points near the vetiver grass and at points within rows.

In agreement with the USDA (1993) on classification of RP based on physical restriction of root growth at all analyzed depths, the points near the vetiver grass presented an intermediate RP (between 100 and $2000 \mathrm{kPa}$ ), while the points within rows displayed an $\mathrm{RP}$ above $2000 \mathrm{kPa}$, which is classified as large. This reduction in RP afforded by the presence of grass assists in the control of erosion on the riverbank slope due to greater water infiltration and lower runoff.

\section{CONCLUSIONS}

The lowest values of soil resistance to penetration at all depths near the vetiver grass are due to the favorable environment created by the grass plants in their rhizosphere, which increases soil moisture.

The higher density of roots contributed to the reduction of soil RP mostly near the vetiver grass plants.

The lack of soil covering within rows is associated with low water content and increased soil RP at all depths analyzed, and resulted in higher compaction (above $2000 \mathrm{kPa}$ ) with a strong restriction on root growth.

The use of vetiver grass in creating a soil bioengineering technique in the riverbanks promoted better soil coverage favoring higher water retention and consequently, decreased the resistance of soil penetration, thus increasing shear resistance.

\section{REFERENCES}

BÖHM, W. Methods of studying root systems. Springer Science \& Business Media, 2012. 188 p.

BOUYOUCOS, G. J. Hydrometer method improved for making particle size analyses of soils. Agronomy Journal, Madison, v. 54, n. 5, p. 464-465, 1962.

CAMPOS, F. S.; ALVES, M. C. Resistência à penetração de um solo em recuperação sob sistemas agrosilvopastoris. Revista Brasileira de Engenharia Agrícola e Ambiental, Campina Grande, v. 10, n. 3, p. 759-764, 2006.

CELIK, I. et al. Effects of long-term organic and mineral fertilizers on bulk density and penetration resistance in semi-arid Mediterranean soil conditions. Geoderma, Amsterdam, v. 160, n. 1, p. 236-243, 2010.

CHONG, C. W.; CHU, L. M. Growth of vetiver grass for cut slope landscaping: Effects of container size and watering rate. Urban Forestry \& Urban Greening, Jena, v. 6, n. 3, p. 135-141, 2007.

COBRA, R. L. et al. Resistência à penetração do solo de uma encosta: Efeitos de espaçamento de plantio e idade da gramínea Vetiver. Revista Agrogeoambiental, Pouso Alegre, v. 4, n. 2, p. 1-9, 2012.

COMPANHIA DE DESENVOLVIMENTO DO SÃO FRANCISCO E VALE DO PARAÍBA CODEVASF. Projeto básico de proteção da 
margem direita do rio São Francisco no perímetro de irrigação Cotinguiba/Pindoba. Disponível em: <http://www.codevasf.gov.br>. Acessado em: 11 mai. 2003.

DE BAETS, S. et al. Root tensile strength and root distribution of typical Mediterranean plant species and their contribution to soil shear strength. Plant and Soil, Dordrecht, v. 305, n. 1-2, p. 207-226, 2008.

DOnAGEMA, G. K. et al. Manual de Métodos de Análise de Solo. 2. ed. Rio de Janeiro, RJ: Embrapa Solos, 2011. 230 p.

FERREIRA, D. F. Sisvar: A computer statistical analysis system. Ciência e agrotecnologia, Lavras, v. 35 , n. 6 , p. $1039-1042,2011$

GOULD, I. J. et al. Plant diversity and root traits benefit physical properties key to soil function in grasslands. Ecology Letters, Madison, v. 19, n. 1, p. 1140-1149, 2016.

HOLANDA, F. S. R. et al. Controle da erosão em margens de cursos d'água: Das soluções empíricas à técnica da bioengenharia de solos. Raega- O Espaço Geográfico em Análise, Curitiba, v. 1, n. 17, p. 93$101,2009$.

HOLANDA, F. S. R. et al. Crescimento inicial de espécies florestais na recomposição da mata ciliar em taludes submetidos à técnica da bioengenharia de solo. Ciência Florestal, Santa Maria, v. 20, n. 1, p. 157-166, 2010.

HOLANDA, F. S. R. et al. Comparison of different containers in the production of seedlings of vetiver grass for erosion control. Revista Brasileira de Ciências Agrárias, Recife, v. 7, n. 3, p. 440-445, 2012.

IORI, P. et al. Resistência do solo à penetração e ao cisalhamento em diversos usos do solo em áreas de preservação permanente. Bioscience Journal, Uberlândia, v. 28, n. 1, p. 185-195, 2012.

JOTISANKASA, A.; MAIRAING, W. Infiltration and stability of soil slope with vetiver grass subjected to rainfall from numerical modeling. Unsaturated Soils: Research and Applications, Austrália, v. 1, n. 1, p. 1241-1247, 2014.

KÖPPEN, W. Climatologia: Común estudio de los climas de latierra. México: Fondo de Cultura Económica 1948. p. 479.

LANZANOVA, M. E. et al. Atributos físicos de um Argissolo em sistemas de culturas de longa duração sob semeadura direta. Revista Brasileira de Ciência do Solo, Viçosa, v. 34, n. 4, p. 1333-1342, 2010.

MAGALHÃES, W. A. et al. Determinação da resistência do solo a penetração sob diferentes sistemas de cultivo em um Latossolo sob Bioma Pantanal. Agrarian, Dourados, v. 2, n. 6, p. 21-32, 2009.

MICKOVSKI, S. B.; VAN BEEK, L. P. H. Root morphology and effects on soil reinforcement and slope stability of young vetiver (Vetiveria zizanioides) plants grown in semi-arid climate. Plant and Soil, Dordrecht, v. 324, n. 1-2, p. 43-56. 2009.

OLA, A. et al. Can we manipulate root system architecture to control soil erosion? Soil, Göttingen, v. 1, n. 1, p. $603-612,2015$.

OLIVEIRA, M. X.; SOUZA, B. S. P. Fragilidade de vertentes: Resistência à penetração versus taxa de infiltração em diferentes subordens de Argissolo na área urbana de São Pedro do Sul/RS. Revista do Departamento de Geografia, São Paulo, v. 25, n. 1, p. $59-77,2013$.

OUYANG, W. et al. Soil erosion and sediment yield and their relationships with vegetation cover in upper stream of the Yellow River. Science of the Total Environment, Barcelona, v. 409, n. 2, p. 396-403, 2010.

PEDROTTI, A. et al. Strengh mechanical penetrance of an albaqualf soil submitted to different systems of tillage. Revista Brasileira de Ciência do Solo, Viçosa, v. 25, n. 3, p. 521-529, 2001.

PODWOJEWSKI, P. et al. Influence of grass soil cover on water runoff and soil detachment under rainfall simulation in a sub-humid South African degraded rangeland. Earth Surf Process and Landforms, New York, v. 36, n. 1, p. 911-922, 2011.

ROCHA, I. P. et al. Meteorological and hydrological variables on occurrence of riverbank erosion along lower São Francisco river. Revista Brasileira de Engenharia Agrícola e Ambiental, Campina Grande, v. 17, n. 2, p. 137-144, 2013.

ROSOLEM, C. A. et al. Crescimento radicular de plântulas de milho afetado pela resistência do solo à penetração. Pesquisa Agropecuária Brasileira, Brasília, v. 34, n. 5, p. 821-828, 1999.

SANTOS, H. G. et al. Sistema Brasileira de Classificação do solo. 3. ed. Brasília, DF: Embrapa Solos, 2013. 353 p.

SILVEIRA, D. et al. Relação umidade versus resistência à penetração para um Argissolo Amarelo 
distrocoeso no recôncavo da Bahia. Revista

Brasileira de Ciência do Solo, Viçosa, v. 34, n. 3, p. 659-667, 2010.

SOUZA, Z. M.; ALVES, M. C. Movimento de água e resistência à penetração em um Latossolo Vermelho distrófico de cerrado, sob diferentes usos e manejos. Revista Brasileira de Engenharia Agrícola e Ambiental, Campina Grande, v. 7, n. 1, p. 18-23, 2003.

STOKES, A. et al. Ecological mitigation of hillslope instability: Ten key issues facing researchers and practitioners. Plant and Soil, Dordrecht, v. 377, n. 12, p. 1-23. 2014.

STUMPF, L. et al. Soil aggregation and root growth of perennial grasses in a constructed clay minesoil. Soil and Tillage Research, Amsterdam, v. 161, n. 1, p. 71-78, 2016.

SUZUKI, L. E. A. S. et al. Grau de compactação, propriedades físicas e rendimento de culturas em Latossolo e Argissolo. Pesquisa Agropecuária Brasileira, Brasília, v. 42, n. 8, p. 1159-1167, 2007

\section{UNITED STATES DEPARTAMENT OF} AGRICULTURE - USDA. Soil survey manual. Washington, DC, USA, Soil Survey Division Staff, (Handbook, 18), 1993. 437 p.

VAZ, C. M. P. et al. Modeling and correction of soil penetration resistance for varying soil water content. Geoderma, Amsterdam, v. 166, n. 1, p. 92-101, 2011.

ZHAO, D. et al. Effect of vegetation type on microstructure of soil aggregates on the Loess Plateau, China. Agriculture, Ecosystems and Environment, Amsterdam, v. 242, n. 1, p. 1-8, 2017. 